\title{
PREVENTION STRATEGY OF COVID-19 IN INDONESIAN PRISONS
}

\author{
Zulfikri \\ Department of Correctional Engineering \\ Polytechnic of Correctional Science, Depok, West Java, \\ Indonesia
}

\begin{abstract}
Corona virus (Covid-19) is a very dangerous virus that is classified as respiratory disease. The spread of the Covid-19 is so fast, especially in Indonesia, more than 39.000 Indonesian people have been infected in less than 4 months and are still counting. Various methods are used by the Indonesian government to avoid the spread of the Covid-19 go into prison. This research analyzes the strategy taken by the Indonesian government in preventing the spread of the Covid-19 into overcapacity prisons in Indonesia. This is descriptive qualitative research through literature studies and articles related to Covid-19 in Indonesia prisons. The results are 7 (seven) strategies in preventing the spread of the Covid-19 into prisons, such as stopping of visits for prisoners, providing booths for spraying antibiotics and disinfectant fluids for visitors, postpone the reception of new prisoners for a while, postponement of trials, releasing prisoners faster especially prisoners during the assimilation period, temporary cessation of coaching activities for inmates, and prohibit transfer of prisoners between prisons. However, there are still problems encountered in implementing these strategies such as lack of prison facilities in Indonesia, lack of awareness of prisoners or prison officers, and lack of community support.
\end{abstract}

Keywords: Strategy, Covid-19, Overcapacity Prisons.

\section{INTRODUCTION}

The corona virus outbreak, also known as Covid-19, was first detected in Wuhan City, Hubei Province, China. This viral infection is associated with many wild animal markets in the area. Patients infected with Covid-19 can easily spread the disease to others. Therefore, patients infected with this virus are recommended to be immediately isolated in the hospital or at home. At the beginning of June 2020, Covid-19 had infected more than 39.000 people of Indonesia.

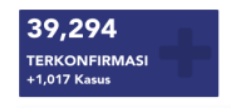

Orang Dalam Pemantauan (ODP)
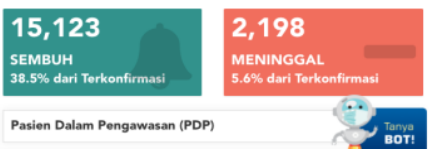

Figure 1. Data of Covid-19 Case (Sources: https://covid19.go.id/peta-sebaran June 16, 2020)

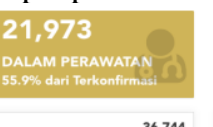

\author{
Ejo Imandeka \\ Department of Correctional Engineering \\ Polytechnic of Correctional Science, Depok, West Java, \\ Indonesia
}

From the can be cured, and 2.198 people have died. Corona virus is one of a number of viruses that cause diseases in mammals and birds. In humans, this virus can cause respiratory infections. Previously, Corona Virus was also found to attack human breathing, including SARS, MERS and Covid-19 viruses. Corona virus can spread through droplets released when exhaling, sneezing or coughing. Water droplets are the main source of corona virus spread. In general, transmission of the corona virus is more susceptible to people who already have an initial illness with symptoms of cough, fatigue, fever, muscle aches, breathing difficulties and others. (Sagar, 2020)

The vulnerable group of people infected with Covid-19 are the elderly, generally people with this criterion have unstable health such as having congenital diabetes hypertension, a weakened immune system, and others. The next vulnerable group are children. Children have a high susceptibility to Covid-19 infection due to the developing immunity. However, in many cases it was found that someone infected with Covid-19 cannot show any symptoms.

Until now there is no vaccine that can cure the Covid-19 virus. Therefore, the best way to avoid infection is to avoid contracting from others. For example, by taking hygienic steps by washing hands with soap or water (containing at least $60 \%$ alcohol) for at least 20 seconds after traveling from a public place. Cover nose when coughing and sneezing. Avoid touching the eyes of the nose or mouth with an unwashed hand. Avoid contact with people who are sick or infected, distance yourself from others, avoid mass collection activities, and wear mouth coverings.

As a result of Covid-19, several countries imposed territorial restrictions, closing industrial sectors, shopping places, sports venues, places of worship, including correctional institutions. The condition of prisons in Indonesia is already over capacity of more than $300 \%$. For example, a room that should be filled with 10 people can be filled with 40 people or more. This has a significant impact on the health of prisoners, especially if there is an infectious disease then all prison inmates will be infected more quickly. 


\section{International Journal of Engineering Applied Sciences and Technology, 2020 \\ Vol. 5, Issue 2, ISSN No. 2455-2143, Pages 37-42 \\ Published Online June 2020 in IJEAST (http://www.ijeast.com)}

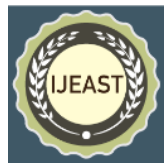

\section{PROPOSED FORMULATION}

Based on the background of the problem, the following research questions can be formulated as follows:

1. What strategies have been undertaken by the Government in preventing the spread of Covid-19 in Overcapacity Prisons?

2. What constraints are faced in the process of preventing Covid-19 in Overcapacity Prisons?

This research objectives can be formulated as follows:

1. Government's strategy in anticipating the spread of Covid19 Virus in overcapacity Prisons.

2. Constraints faced in the process of preventing the entry of Covid-19 Virus in overcapacity prisons.

This research uses a qualitative approach with literature study, experts, books, and other supporting data relating to area of research. Qualitative approach is a relationship, activity, view, attitude, which reveals the ongoing process (Winarnos, 1982).

\section{EXPERIMENT AND RESULT}

\section{Overcapacity Prisons}

The definition of over capacity is the amount of space that exceeds the maximum number of prisoners that should be able to be accommodated in an institution. The International Committee of the Red Cross (IRCR) recommends the minimum space needed for prisoners or detainees to sleep, including:

1. 1.6 square meters for sleeping area but does not include toilet and bathroom.

2. 5.4 square meters per person for a single residential cell.

3. 3.4 square meters per person for shared residential cells including using divan beds.

The application of this density specification also depends on the actual situation in a particular context in a country. The average prison in the countries of the world experience overcrowding / over capacity, even over capacity is a special feature for modern prisons that have stood since the 19th century. (Coyle, 2018).

According to the world prison population that the world's prisoner population has increased by $25-30 \%$, the ratio of world prisoners has increased by around 6\% from 136 per 100,000 population of the world's population which is currently 144 . Based on data from the Institute for Criminal Policy Research, in 2018, more than 10.35 million people in the world are in prison either as prisoners or as prisoners. This shows that prison population density is increasing in any country. To describe the situation of overcapacity in various countries the occupancy rate is used (the number of prisoners per prison official capacity) as a benchmark the term overcrowding (occupancy rate> 100\%) is also used and there is also a critical density of occupancy rate above $120 \%$ and the latter is called extreme overcrowding, which is an occupancy rate above $150 \%$.

In Indonesia, the definition of overcapacity prisons is the number of prisoners exceeding the capacity of prison set by the government. Referring to the Circular of the Director General of Corrections No: E-PS.01.10-31 of 2015, states that each prisoner must occupy a room of space of $5,4 \mathrm{~m}^{2}$, with the formula that the capacity of residential rooms is X (room area) $/ 5.4 \mathrm{~m}^{2}$, while for the capacity of the bed is $2 \mathrm{~m}^{2}(\mathrm{p}=2 \mathrm{~m}$ and $1=1 \mathrm{~m}$. While the formula for the bed is $Y$ (area of occupancy room) $/ 2 m^{2}=n$ (person).

By considering the formula above, we can draw the conclusion that the average prison in Indonesia has exceeded capacity. This can be seen from the following table:

Table 1. Prison capacity in Indonesia

\begin{tabular}{|l|l|l|l|c|}
\hline No & Year & Inmate & Capacity & Advantages \\
\hline 1 & 2015 & 176.754 & 119.797 & $147 \%$ \\
\hline 2 & 2016 & 204.551 & 119.797 & $170 \%$ \\
\hline 3 & 2017 & 232.081 & 123.481 & $188 \%$ \\
\hline 4. & 2018 & 256.273 & 126.273 & $202 \%$ \\
\hline 5 & 2019 & 269,846 & 130.512 & $206 \%$ \\
\hline
\end{tabular}

Over capacity prisons create various obstacles in the form of ineffective process of guiding implementation for inmates and the emergence of security and order disturbances. This is due to the unbalanced amount of human resources available with the number of dwellings, and the lack of facilities and infrastructure used to support activities in prisons. Overcapacity in prisons is caused by several things as follows:

1. The addition of prisoners is not balanced with prisoners released. There are several types of expenses, such as, spending due to parole, expenditure due to conditional leave and expenses due to actual free. According to Government Regulation No. 99 of 2012, the release of prisoners is more stringent, especially for cases such as drugs, corruption, terrorists, and money laundering.

2. Criminal rates increased. It impacts to the number of prisoners and detainees who enter prison and detention centers. The policy of law enforcement officials is more prioritizes to put prisoners in jail rather than restorative justice. (Hartney, 2006). There are other alternative punishments that can be used by law enforcement such as payment of fines, diversion or social punishment and restorative justice policies for small criminal cases. Prisons and detention centers should have an argument to minimize the overcapacity problem. Moreover, negative stigma from the community towards prisoners was not easily erased. Prisoners are still considered ex-criminals who are always 


\section{International Journal of Engineering Applied Sciences and Technology, 2020 \\ Vol. 5, Issue 2, ISSN No. 2455-2143, Pages 37-42 \\ Published Online June 2020 in IJEAST (http://www.ijeast.com)}

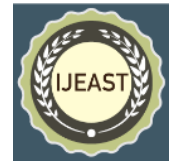

ostracized and set aside in relationships. This is a trigger for ex-convicts to return to do crime and anti-social (Farrington \& Murai, 2014).

In addressing overcapacity problem in prisons, the government has issued several policies including:

1. Transferring prisoners from overcapacity prisons to other prisons. For example, transferring prisoners from the overcapacity prison in Jakarta to the Nusa Kambangan Prison, Gunung Sindur Prison or others.

2. Speed up the release of prisoners with the Crash Program. Crash Program is a program issued by the Director General of Corrections to speed up the release of prisoners, through conditional requirements, parole, or leave before release. This program has been implemented several times and has succeeded in reducing overcapacity problem in prisons and detention centers.

3. Carry out diversion and restorative justice programs especially for child prisoners. This program can reduce the number of children who will be sent to prison for successfully finding a win-win solution between victims and community, so that this process does not have to go to court.

4. Prisons should have a balanced criteria of its facility. The number prisoners and its room, blocks and cells, staff resources, infrastructure, accommodation and the rights of prisoners as well. If all of this criteria cannot be balanced, then the coaching programs cannot be implemented properly, the rights of the inmates cannot be fulfilled, and other issues such as emergence of diseases will appeared.

Based on the philosophy of coaching Saharjo, there are 10 (ten) correctional concepts in Indonesia (Makaro, 2006), such as:

1. Protect and provide provisions for life so that they can carry out their role as good and useful citizens.

2. Dropping a crime is not revenge from the State, the only suffering experienced by inmates is the loss of independence.

3. Penance cannot be achieved through torture but with guidance.

4. The state has no right to make someone worse than before he entered the Correctional Institution.

5. During the loss of freedom of movement prisoners must not be exiled from society.

6. Work given to prisoners must not merely fill up free time and is intended only for the benefit of the State at any time.

7. Guidance must be based on Pancasila.

8. Everyone is human and must be treated as a human, even if he is lost.
9. Prisoners are only sentenced to loss of freedom of movement.

10. For the guidance and guidance of prisoners, the necessary means are provided.

\section{Impact of Covid-19 on Overcapacity Prison}

Over capacity prisons are very vulnerable to the emergence of disease, this is due to the imbalance of residential facilities and infrastructure compared to the increase in the number of prisoners. As a result, rooms become crowded and more vulnerable to diseases, especially infectious diseases. This is compounded by the limited clean water and air ventilation, so there is no healthy air circulation. This results in a dark, damp, and poor lighting condition. This will lead to the development of various infectious diseases in prisons and detention centers. The following data is one of the overcapacity prison in Bogor, West Java, with the number of prison residents is 1.443 people:

Tabel 2. Disease data at Bogor Prison over capacity

\begin{tabular}{|c|l|c|}
\hline No & Types of diseases & Amount \\
\hline 1 & Skin disease & 555 \\
\hline 2 & Digestive ailments & 269 \\
\hline 3 & Respiratory disease & 300 \\
\hline 4 & Scabi & 63 \\
\hline 5 & Blood circulation & 92 \\
\hline 6 & Others & 308 \\
\hline \multicolumn{2}{|c|}{ Total } & $\mathbf{1 5 8 7}$ \\
\hline \multicolumn{2}{|c|}{ (Source: Bogor Prison, Feb 2020) } \\
\hline
\end{tabular}

Based on the table above, we can see that the spread of infectious disease in Bogor Prison is very high. Skin disease is an infectious disease with the highest level of susceptibility, 555 people infected, then respiratory disease, digestive disease, and others. It can be predicted that if infectious diseases go into prisons, are classified as very dangerous such as Covid-19, it will easily spread through interactions between prisoners. The method of preventing the spread of corona viruses in prisons is different from the prevention of spreading outside prisons. For example, through the Social Distancing Program, which is maintaining social distance, may not be carried out because of the limitations of prisons as part of the total institution. Total institution is a place for people with the same background, the same treatment and the same rules for a certain period of time, and separated from the community.

Correctional Institutions as part of the total Institution has an effect on inmates, because of their togetherness in the same room space, also the same clothes and the same facilities and infrastructure. It will certainly have a bad influence if there is an inmate infected with Covid-19. This is in line with Contagion Theory, where a crowd can cause a hypnotic effect on an 


\section{International Journal of Engineering Applied Sciences and Technology, 2020 \\ Vol. 5, Issue 2, ISSN No. 2455-2143, Pages 37-42 \\ Published Online June 2020 in IJEAST (http://www.ijeast.com)}

individual. The concept of contagion emerged in the sixteenth century by Giralomo Fracastoro (1478-1553), an epidemiologist, Fracastoro distinguished three types of contagion, namely:

1. Types of contagion that can be transmitted through direct contact, touching, kissing and sexual relations.

2. Types of contagion that are transmitted through intermediate objects (they are not infected but retain seeds and then transmit them to others) for example through clothing, towels and handkerchiefs.

3. Types of contagion that can be transmitted at long distances.

According to this concept pain occurs because of the contact process that intersects with the source of the disease. It can be said at this time that there was thought that the concept of transmission at that time did not recognize germs or bacteria, but the mechanism of transmission according to the contagion was similar to the method known today in the era of bacteriology.

This theory can be proven by the overcapacity condition in which one room contains 40-50 people, with such a dense room will facilitate the spread of infectious diseases, through contact between inmates with other prisoners.

Overcapacity prisons exceeds $300 \%$ or even $500 \%$ are still mostly found in Indonesia, for example Banjarmasin Prison with the capacity of 366 people inhabited 2,688 people (over capacity 644\%), Tarakan Prison with the capacity of 155 people inhabited 996 (over 650\% capacity), Labuan Ruku Prison with the capacity of 300 people inhabited by 1,770 people (over $640 \%$ capacity), Bagan Siapi api Detention Center with the capacity of 98 people inhabited 810 people (over capacity $836 \%$ ), Takengon Detention Center with the capacity of 65 people inhabited 495 people (over capacity of 640\%) and there are still many prisons with similar conditions.

The atmosphere of a crowded room, lack of lighting, inadequate water conditions in a hot room, will make the prisoner's room into a sick building (Sick Building Syndrome) and become a medium for spreading disease. Sick Building Syndrome (SBS) according to Environmental Protection Agency (1991) is a term to describe situations where buildings or buildings with acute health problems and the effects caused when in a building with acute health problems. This is identical to the condition of overcapacity prison with conditions of a dense atmosphere, lack of lighting, limited water, humid, and others. According to Aditama (2002), there are 7 (seven) categories of diseases caused by Sick Building Syndrome:

1. Irritation of mucous membranes.

2. Nasal irritation.

3. Neurotoxic disorders (nerve disorders).

4. Lung and respiratory disorders.
5. Skin disorders, dry skin, itching.

6. Disorders of the digestive diarrhea.

The vulnerability of the disease in overcapacity prisons become an easier tool for the spread of the Covid-19 virus. A weakened immune system will be more easily infected by Covid-19 Virus. The symptoms of Covid-19 can be unseen, but when the immune system is weak, they can experience more severe symptoms and also quickly become infectious to others.

The government should has an important role to prevent the spread of Covid-19. It is important because prisons and detention centers can be an incubator of Covid-19 spread, if it left unchecked, it will become a mass grave for prisoners.

\section{Strategies in Preventing Covid-19 in Indonesian Prisons}

The Indonesian government has taken several steps to prevent the spread of Covid-19 into prison, including:

\section{Stopping of Visits for Prisoners}

The prohibition of visits is an attempt to break the chain of virus transmission from visitors or from prisoners. Although this is very hard to accept for prisoners who are accustomed to welcome the family visits, finally this policy can be understood for the common good. The the large number of visitors each day, has a significant impact on the transmission of Covid-19. Therefore, the government needs to take steps to stop visiting prisoners within a certain time.

Prisoner's visit is a form of coaching that involves the community directly to prisoners. It brings prisoners closer to their families or also called inward assimilation. Proximity of prisoners to their families will certainly be a motivation for prisoners to always behaved during serving their sentence. It also made them aware to regulations as well.

In order to maintain communication between prisoners and their families, a number of prisons and detention centers provide telephone or video call. This facility can reduce prisoner tensions due to the impact of Covid-19 on their family visits. Some prisons that use video call facilities such as Bali Kerobokan Prison, Tanjung Gusta Prison, and so on. The Tanjung Gusta Prison Head said that this policy was implemented because of the lock down as part of the anticipation of preventing Covid-19 in prison. However, this policy causes disappointment for both prisoners and families.

\section{Providing booths for disinfectant}

It is necessary to provide booths disinfectant to officers, guests, and whoever come to prison. It kills bacteria and viruses that attach to the human body. It is based on policy of Director General of Corrections No. PAS-08.OT.02.02 year 2020, about concerning the prevention, handling, control and recovery of Covid-19 in prisons and detention centers. It instructs spraying disinfectant routinely in the prisons area, residential blocks, 


\section{International Journal of Engineering Applied Sciences and Technology, 2020 \\ Vol. 5, Issue 2, ISSN No. 2455-2143, Pages 37-42 \\ Published Online June 2020 in IJEAST (http://www.ijeast.com)}

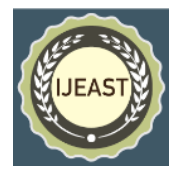

porter rooms, visiting places and other public areas, including toilets, children's play rooms, and nursing rooms.

\section{Postpone an addition of new prisoners for a while}

Every day, prisons and detention centers are always get new prisoners from the Police, Attorney General's Office, or the Court. New prisoners who enter prison or detention can become Covid-19 carriers. The postpone of acceptance of detainees and prisoners aims to reduce the density of prisons and detention centers. The Minister of Law and Human Rights also supports this policy by writing to the Attorney General's Office, the Police and the Supreme Court to temporarily stop hearings for detainees.

Based on data from 2 (two) Detention Centers in Jakarta, it can be seen that the average admission of new prisoners in Salemba Detention Center is 25 people each day and 165 people receive daily visits, with residential capacity of 4.159 people. For Cipinang Detention Center, the average number of new prisoners is 30 each day and an average of 400 daily visitors, with residential capacity of 3.773 people. Based on these data, it is known that detention centers have many new prisoners and visitors every day. This is very dangerous and very vulnerable to Covid-19 disease.

According to the Minister of Law and Human Rights policy to temporarily suspend the visit of prisoners is a form of attention from the government to protect its citizens without any discrimination. Prisoners are also human beings that must be treated as humans. This is in line with the ten Principles of Corrections, it states that prisoners are human and must be treated as humans, and Nation has no right to make prisoners worse than before entry the prison. It shows that Indonesian government paid more attention in preventing the spread of Covid-19 in prisons and detention centers. Different thing happens in Colorado Prison, United States. The elements of the community are more concerned, they try to write to convince the government that Covid-19 is very dangerous if it infects prisoners. Also, they ask government to immediately release prisoners and detainees held in Colorado prisons. (Colorado Criminal Justice Reform, 2020)

\section{Postponement of Trial}

The Indonesian government has taken a formal step to the Police, Prosecutors and Courts to postpone the trial. The trial process is very vulnerable to Covid-19 spread, because it must issue a large number of prisoners each day to the court. For example, Salemba prison issued 120 inmates for the purposes of hearings in the Central Jakarta, West Jakarta, and North Jakarta Courts. In the implementation, there was the possibility of inmates carrying Covid-19 virus during the trip of trial.

\section{Releasing prisoners faster, especially prisoners during the assimilation period.}

The assimilation period is the time to prisoners mingle with the community, on condition that they have served half of their sentence. The aim is to make prisoners accustomed to the community before being released. It is expected that the prisoners can interact with the community again. Prisoners can show to the community that they have become a good human being. It is also hoped that the community can accept the prisoners. In the pandemic conditions, assimilation was carried out with a different purpose. Prisons conditions are very risky in the spread of Covid-19. Assimilation activities during the Covid-19 period required the prisoners to stay at home only, and undergo all government programs related to anticipation of Covid-19 spread.

The release of prisoners to carry out assimilation at home is also the policy of the Indonesian government in order to reduce overcapacity in prisons and detention centers. But in its implementation, the community needs to be well socialized. Some people assume that the exemption was carried out unconditionally, it rises negative sentiment to community. In fact, the release of prisoners to take assimilation does not applied to all prisoners, only for prisoners who have fulfilled certain conditions. It based on Director General of Corrections Rule, No. PAS. 947. PK. 01.04.04 - 2020 concerning the release of prisoners and children through assimilation and integration in the context of preventing and controlling the spread of Covid-19 in prisons and detention centers. Indonesian government has released more than 38.000 prisoners to undergo assimilation and Integration process.

There is a difference between assimilation and integration activities. The release of assimilation is temporary in case of it violates the rules of assimilation, it can be immediately taken back into prison. Whereas the release of integration was carried out after the prisoners served $2 / 3$ of their criminal sentences. It supervised by probation officers and Prosecutor's Office.

\section{Temporarily stop prisoner's coaching programs}

In the implementation of fostering for prisoners in prison and detention often involves third parties from outside, such as scouting, recitation for Muslim inmates, and services for Christian prisoners. This activity is certainly prone to the spread of Covid-19, where if the coaching activity is carried out by gathering prisoners in a certain place and interacting with one another.

\section{Prohibit transfer of prisoners to other prisons}

Transfer of prisoners is a routine matter in prisons. The transfer of prisoners is usually carried out to prisons that are not yet dense either inside or outside the city. These activities should be prohibited for a while for the sake of healthy prison. Because of its huge impact to prisoners, families, and officers, it should always be supported and socialized. Other government policies that might be applied against the spread of the Covid-19 in prisons are always washing hands, and wearing masks in the area. 
Another government policy related to preventing the spread of Covid-19 is by issuing Regulation No. 21 of 2020, concerning Social Distancing. This policy was strengthened by Minister of Health about guidelines for the implementation of massive social restrictions in order to accelerate the handling of Covid-19. In general, it regulates the following matters:

1. Restrictions of educational activities at school.

2. Restrictions on religious activities.

3. Restrictions on public facilities.

4. Limitation of transportation modes.

5. Limitation of social cultural activities.

6. Limitation of other activities in the aspects of security and defense.

However, not all of these policies can be implemented in prisons because of its density and its possibility to keep a distance between inmates.

\section{CONCLUSION}

It can be concluded that to prevent Covid-19 in prisons and detention centers in Indonesia, there are several strategies can be used, such as:

1. Stopping family visits for prisoners.

2. Releasing the prisoners faster in certain conditions.

3. Postpone an addition of new detainees from other institutions such as Police, Attorney General's Office, and Court.

4. Postpone court proceedings.

5. Making a booth for disinfectants who enters prisons or detention centers, providing hand washing and cleaning soap in the open area.

6. Temporarily stop prisoner's coaching programs.

7. Stopping transfer of prisoners to other prisons.

Constraints faced in preventing the spread of Covid-19 into prisons are lack of prison facilities in Indonesia, lack of awareness of prisoners or prison officers, and lack of community support. This can be seen from the large number of prisoners and society who protest against the Covid-19 prevention policy.

In preparing policies for preventing Covid-19 in prison, government should involve experts, community representatives, and correctional departments. This will provide understanding to the public, and stakeholders, also avoiding the emergence of negative perceptions. In addition, the policies must be formulated technically in the procedures so that it does not cause doubts for officers in the field.

\section{REFERENCE}

[1] Coyle, A. 2018. Managing prison overcrowding: A European perspective. Rencontre Européenne des Directeurs d'Administration Pénitentiaire Ministère de
Justice. Place Vendôme, Paris,11 July 2008. International Centre for Prison Studies, London 2008.

[2] Circular Letter of Director General of Corrections. 2019. No: PAS 1386. PK.01.04.06 Year 2019.

[3] Circular Letter of Director General of Corrections. 2005. No: E-PS.01.10.31. May, 182005.

[4] Criminal Justice Reform. 2020. Request for immediate action to address COVID-19 in Colorado's jails and prisons. ACLU of Colorado: March 17, 2020.

[5] Farrington, Dafid P., Murai, Josesph. 2014. Labelling Theory Emprical Test. Transaction Publisher, 2014, Pg. 26.

[6] Government Regulation. 2012. Requirements and Procedure for the Implementation of Prisoners' Community Rights. No. 99 year 2012.

[7] Hartney, Christopher. 2006. US Rates of Incarceration: A Global Perspective. Research of National Council on Crime and Delinquency, November 2006. Pg. 1.

[8] ICJR. 2018. Strategi Menangani Over Crowded di Indonesia. ICJR.

[9] J, Mullen. 1985. Prison Crowding and Evolution Of Public Policy National Institute Of Correction. Baverly Hills, 478.

[10] Letter of Minister of Law and Human. 2020. No: MHH. PK.01.01-04, March 24, 2020.

[11] Makaro, Mohammad Taufik. 2006. Renewal of Indonesian Criminal Law. Yogyakarta: Kreasi Wacana, 2006, Pg. 143.

[12] Richie, Cooley. 2018. Corona Virus Is Not The End Of The World.

[13] Sagar. 2020. Let's Fight Corona Virus Disease (Covid-19) Together. New life books. March 14, 2020. Pg. 4).

[14] Steven, Lea. 2020. How To Beat Virus. Bloo Zoo.

[15] Surakhmad, Winarno. 1982. Introduction to Scientific Research. Bandung: Tarsito.

[16] Tjandra Y. Aditama., Sita L. Andarini. 2002. Sick building syndrome. Medical Journal of Indonesia, Vol 11 No 2 (2002): April-June, Pg. 124.

[17] Wealth Health Organisation. 2020. Treatment Important Information Covid-19. WHO, Jenewa.

[18] Yilmaz, Olmez. 2019. Corona Virus. Google e-book. 